\title{
The Guarantee Mechanism of Small Business Lending
}

\author{
Sabitova N.M.a \\ Khayrullova A.I. ${ }^{\mathrm{b}}$ \\ a b Kazan Federal University, Institute of Management, Economics and Finance, Kazan, 420008, Russia
}

\section{Doi:10.5901/mjss.2015.v6n1s3p164}

\section{Abstract}

The state and the problems of the small business system in the Russian Federation are primarily associated with its financial conditions. Insufficient rate of small business growth relates to a variety of causes, including lack of availability of the long-term lending resources. Small business lending conditions need state-financing backing. This publication substantiates the need for growing such a form to support small business as the guarantees for getting access to supplementary financial resources.

Keywords: Small business, governmental control, financial backing forms, lending, rates of interest, loan arrears.

\section{Introduction}

The small business system serves to find solution to the key problem of any state - the employment of population. The share of small business segment varies from $50 \%$ to $75 \%$ of the total employment in the EU countries and over $50 \%$ in the USA while the contribution of small business into the total employment in Russia is $17-18 \%$. According to the official figures of Rosstat, the Federal State Statistics Service, 11,695.2 thousand persons were engaged in the small business activity in 2013 and the annual average number of employed was 67,901 thousand persons or 5.8\% of the total employment. Additional tools are required for development of this system that will ensure favourable financial conditions of their functioning.

Affordability of lending resources is of most importance to the growth of the small business system. Taking significant risks of small business lending into consideration, a loan guarantee mechanism should be developed and provided to ensure lending the small business.

\section{Theory}

The matter of governmental financial backing to the small and medium-sized enterprises was covered by such authors as Walczak, D. and G.Voss [1], Cowling, M., W. Liu, A. Ledger [2], studied the positive effect of small business lending guarantees.

There are many tools of governmental financial backing provided to small business, including budget investments, governmental guarantees and subsidies. In particular, since 2008 the subsidies allocated by the federal budget to support small business have been seeking to grow. However, this level of small business growth does not match the level of other countries.

The need for further availability of loans remains actual in connexion with this. The factors that prevent expansion of small business lending are: small business size; minor part of own funds in the capital structure and absence of liquid assets; short credit history or its absence at all; high credit risks and limitations to secure the mentioned loans; mismatch of small business profitability with the interest rates on credit; instable legal system, including taxation. The authors see the solution to the problem of small business lending in perfection of the guarantee mechanism.

\section{Results}

Lending institutions unwillingness to lend the small enterprises is also explained by loan debt growth. The total loan debt amounts of small and medium-sized enterprises nationwide are listed in Table 1. Furthermore, it should be mentioned that debt arrears of both small and medium-sized enterprises increase in the total arrear volume. So, if the debt arrear was 19\% in 2009, it raised to $26 \%$ by 2013. 
Table 1. Debt arrears of small and medium-sized enterprises over a period of 2010-2014

Billions of Rubles

\begin{tabular}{|l|c|c|c|c|c|c|}
\hline Period & 2010 & 2011 & 2012 & Within 7 months of 2013 & 2013 & Within 7 months of 2014 \\
\hline Total, including & 3227 & 3843.5 & 4494.2 & 4938.7 & 5160.6 & 5389.9 \\
\hline Ruble lending & 2992 & 3616.7 & 4288.9 & 4684.1 & 4878.0 & 5084.0 \\
\hline Foreign currency lending & 235 & 226.8 & 205.3 & 254.6 & 282.6 & 305.9 \\
\hline
\end{tabular}

Increase in arrears for the period under review suggests that the small business system fails to be liable for debts and the lending conditions are stringent. This, in turn, results in that the borrowings taken by small and medium-sized enterprises are negligible in the total corporate bank loans in Russia as compared with other countries (Table 2).

Table 2. Borrowings of small and medium-sized enterprises in the total corporate bank loans in 2008-2011. (according to MSP Bank studies) [17] (\%)

\begin{tabular}{|c|c|c|c|c|}
\hline Country & 2008 & 2009 & 2010 & 2011 \\
\hline Switzerland & 81.3 & 80.3 & 80.1 & 79 \\
\hline Republic of Korea & 82.6 & 83.5 & 81.5 & 77.7 \\
\hline Portugal & 77.7 & 77.4 & 77.3 & 76.8 \\
\hline Hungary & 60.6 & 60 & 54.5 & 54.5 \\
\hline Thailand & 26.6 & 26.9 & 38.4 & 36.8 \\
\hline Slovenia & 48.2 & 47 & 51.8 & 54.3 \\
\hline USA & 27.7 & 27.6 & 29 & 26.5 \\
\hline Russia & 19.9 & 21.3 & 23.7 & 22.5 \\
\hline France & 20.4 & 20.2 & 20.6 & 20.9 \\
\hline United Kingdom & 18 & 20.8 & 21 & 20.6 \\
\hline Italy & 17.9 & 18.3 & 19 & 18.3 \\
\hline Canada & 15.6 & 17.9 & 17.5 & 17.5 \\
\hline Chile & 15.2 & 17.5 & 18.2 & 17.4 \\
\hline Sweden & 88.5 & 92.4 & 91.1 & $\mathrm{n} / \mathrm{a}$ \\
\hline
\end{tabular}

Notwithstanding that the borrowings of small and medium-sized enterprises have increased in the total corporate bank loans in Russia by 2.6 percentage points over 4 years, this figure does not achieve the average value of $33.8 \%$ for the above countries in 2011. This fact can be primarily explained by high lending interest rates provided to the small enterprises. The analysis of lending rates in other countries (Table 3) shows that the rates for small enterprises are higher than those granted to other market participants. However, the lending rates are much lower in the considered countries than in Russia.

Table 3. Lending rates for small and medium-sized business [17] \%

\begin{tabular}{|l|c|c|c|c|c|c|}
\hline Period & 2007 & 2008 & 2009 & 2010 & 2011 \\
\hline Switzerland & n/a & n/a & 0,86 & 0,88 & 0,92 \\
\hline Mean lending rate (for loans not exceeding 1 million Swiss Francs) & n/a & n/a & 2,21 & 2,11 & 2,08 \\
\hline Mean lending rate (for loans in excess of 1 million Swiss Francs) & n/a & 4,54 & 3,47 & 3,49 & 3,52 \\
\hline United Kingdom & $\mathrm{n} / \mathrm{a}$ & 3,71 & 2,36 & 2,19 & 2,45 \\
\hline Mean lending rate for small and medium-sized business & 5,63 & 5,37 & 4,46 & 4,08 & 3,83 \\
\hline Mean lending rate for business & 5,1 & 4,8 & 3,72 & 3,47 & 2,86 \\
\hline Czech Republic & 4,91 & 5,43 & 3,93 & 3,27 & 3,69 \\
\hline Mean lending rate for small and medium-sized business & 4,71 & 5,01 & 2,25 & 2,05 & 2,75 \\
\hline Mean lending rate for business & 7,96 & 5,16 & 3,82 & 4,09 & 3,95 \\
\hline France & 6,75 & 4,29 & 2,99 & 3,23 & 3,07 \\
\hline Lending rate (for loans less than 1 million Euro)
\end{tabular}


Thus, the nominal interest rate for loans in excess of 3 year given to the Russian small and medium-sized enterprises as of July 2014 averages 13.27\% while the actual rate including multiple bank charges and payments is 17\% and higher. Regarding the corporate loans in general, is should be noted that the interest rate for loans in excess of 3 years averaged $11.9 \%$ as of July 2014. The same is true for short-term loans. Moreover, the commerce and services received most of the loans (up to 80\%). The small and medium-sized production enterprises are restricted in access to bank financing as before as the security requirements are stringent to them. The situation is worsening now by the reason that the commercial banks begin with reducing their limits for small and medium-sized enterprises and tighten the requirements to these borrowers.

As practice of different countries shows, using guarantee mechanisms is the most effective tool to increase affordability of lending resources for small and medium-sized business (Table 4).

Unlike the direct budget financing of small business, the guarantee mechanisms are lower in cost; they do not prevent competition and contribute to risk assessment of both the creditors and borrowers (small enterprises) and drafting the credit agreement terms as well as strengthening ties between them. At the same time, the guarantees are a form to protect the lending agencies from high risks of small business lending.

Table 4. Amount of loans taken by small and medium-sized business and government guarantee secured, in 2007-2011 for the below countries [17]

\begin{tabular}{|c|c|c|c|c|c|}
\multicolumn{7}{|c|}{ Million Euro } \\
\hline Country & 2007 & 2008 & 2009 & 2010 & 2011 \\
\hline Canada & 900 & 975 & 900 & 975 & 975 \\
\hline Chile & 445.7 & 413.1 & 1252.5 & 2258.3 & 3077.9 \\
\hline Czech Republic & 114,5 & 197.1 & 369.6 & 389.7 & 24.4 \\
\hline Denmark & 41 & 29.5 & 37 & 162 & 259.2 \\
\hline France & 5850 & 8861 & 11267 & 10883 & 8826 \\
\hline Hungary & 1296.8 & 1483.8 & 2041 & 1604.9 & 1486.5 \\
\hline Italy & 2,3 & 2,3 & 4.9 & 9.1 & 8.4 \\
\hline Republic of Korea & 27790 & 30030 & 39410 & 39270 & 38850 \\
\hline The Netherlands & 09 & 400 & 370 & 945 & 1040 \\
\hline Portugal & 740 & 1552 & 4961 & 6285 & 6147 \\
\hline Russia & - & - & 964.7 & 1656.6 & 3043 \\
\hline Serbia & - & 10.5 & 2.6 & 2.2 & - \\
\hline Slovakia & 115 & 157 & 143 & 139 & 167 \\
\hline Spain & 5210 & 7053 & 5906 & 7236 & 7502 \\
\hline Sweden & 18.8 & 15.7 & 12.8 & - & - \\
\hline Thailand & - & - & 557324.8 & - & - \\
\hline Turkey & 32.6 & 174.3 & 342.3 & 563.8 & 702.3 \\
\hline United Kingdom & 242.7 & 208.7 & 890.7 & 690.3 & 425.2 \\
\hline USA & 15.8 & 12.3 & 11.8 & 17.2 & 14.3 \\
\hline
\end{tabular}

The existing Russian guarantee mechanism, which is implemented through the federal Guarantee Fund and the regional funds, has its own disadvantages. Despite ever-augmenting number of regional funds, one can see some drawbacks of the guarantee mechanisms. The lending agencies that unwish to lose their borrowers misapply to the Guarantee Fund by sending entities unable to pay for loan guarantees. The analysis of the Russian Government Resolution No. 825 dated 14 August 2012 "Concerning the Procedure for Providing the Government Guarantees in 2012 on Credits or Bonded Loans Used by Legal Bodies for the Purposes Determined by the Russian Federation Government as Part of Measures to Enhance Economic Growth Stability if the Financial Markets Decline" brings to the conclusion that this Resolution does not clearly reflect the objectives of attraction of guaranteed loans and determine the criteria of the position of a company claimed to the guarantee.

The Russian Government is regarding different alternatives of financial backing of banks for small business lending. So far, the Government is going to complete the conceptual design of a Loan Guarantee Agency by the end of 2014. We think that this form of support will be the most effective one. This Loan Guarantee Agency being a non-bank credit-deposit organisation will be $100 \%$ owned by the Federal Government. The Agency is designed for lodging investment loan guarantees to the small and medium-sized enterprises for 2-7 years in the amount of 50-270 million Rubles if their own pledge is insufficient. 
Both the national guarantee agencies system and the Loan Guarantee Agency being a core of federal guarantee fund will increase affordability of lending resources to be lodged to the small and medium-sized enterprises, specifically, to those of uncommercial sector. The goal of the Agency is to provide regional guarantee organisations of all Russian regions with counter-guarantees. The key objectives of the Agency will be:

- Reduction in credit risks of small business investment projects by means of risk sharing with the pecuniary institutions;

- Enhancement of lending conditions for small and medium-sized business;

- Increase in long-term lending capacity;

- Increased capabilities of regional guarantee agencies to provide loan guarantees to the small and mediumsized business and enhancement of their efficiency.

According to the Agency's 5-year business plan, the following financial and economic results (provided that the capitalisation is 30.0 billion Rubles) are expected:

- The total guarantee amount: 217.8 billion Rubles;

- The total guaranteed investment loans: 435.0 billion Rubles;

- The total number of guarantees granted: 6900;

- The number of small and medium-sized enterprises having guaranteed loans will be 79.5 thousand entities;

- The percentage of loans granted to the small and medium-sized enterprises and secured by the national lending agencies system will reach $4.0 \%$ of the total loan debts of small and medium-sized business.

Therefore, this mechanism of guarantee support through the Loan Guarantee Agency will be primarily targeting the small and medium-sized enterprises that realise their investment project in the regions.

\section{Conclusions}

Generally, the small business in Russia does not yet meet the level of other developed countries. This relates chiefly to the financial disadvantages of this economic system notably it associates with severe lending conditions. The result is that the small business system raises concerns from the state due to:

- Unsettled problems of unemployment;

- Reduction of investment programmes for small and medium-sized business due to limitation of long-term lending resources;

- $\quad$ Failure to meet import substitution requirements.

One of the options to solve the problem of loan affordability for small business is the national guarantee backing through the Loan Guarantee Agency. The efficient risk control and appreciable social-and-economic effect of the projects is the main advantage of this support. Furthermore, the regional guarantee funds should develop and employ special lending products for the small business to facilitate the governmental contracts in order to progress the guarantee mechanism.

\section{References}

Varlamova J.A., Larionova N.I. Economic behavior of households: cross-country comparison. Life Science Journal 2014; 11(6s): 409413.

I.Sh. Khasanov, Three-sector structure of the national economy of Russia // Asian Social Science, Volume 10, 2014, Pages 217-224.

Cowling, M., W. Liu and A. Ledger, 2012. Small business financing in the UK before and during the current financial crisis. International Small Business Journal, 7: 778-800.

Milea, O.M., Pascu, E., Nedea, P. S., May 2014. SMEs in the European economy. Quality - Access to Success, SUPP.2: 215-219.

Sahut, J.-M., Peris-Ortiz, M., 2014. Small business, innovation, and entrepreneurship. Small Business Economics, 4: 663-668.

Wang, X., Chu, B., 2012. Financing governance from business group of small and medium-sized enterprises - A empirical study of small and medium-sized listed companies in China. Proceedings of the 2012 24th Chinese Control and Decision Conference, 6244659: 4118-4123.

Kvyk, M.I., Tsehelyk, H.H., May 2014. Optimal allocation of small business loans subject to their needs. Actual Problems of Economics, 5: 498-505.

De Maeseneire, W., T. Claeys, June 2012. SMEs, foreign direct investment and financial constraints: The case of Belgium. International Business Review, 3: 408-424.

Abbasian, S., Yazdanfar, D., Hedberg, C., 2014. The determinant of external financing at the start-up stage - Empirical evidences from swedish data. World Review of Entrepreneurship, Management and Sustainable Development, 1: 124-141.

Liu, Q., 2013. Analysis on financing efficiency of listed small and medium business. Journal of Theoretical and Applied Information Technology, 1: 158-162. 
Benkraiem, R., Miloudi, A., January 2012. ICT small businesses' access to bank financing. Journal of Applied Business Research, 1: 2736.

Valentin, A. and T. Henschel, 2013. Do guarantee banks mitigate credit restrictions for SMEs? International Journal of Entrepreneurship and Small Business, 4: 481-496.

Zambaldi, F., Aranha, F., Lopes, H., Politi, R., March 2011. Credit granting to small firms: A Brazilian case. Journal of Business Research, 3: 309-315.

Chakraborty, A., Mallick, R., December 2012. Credit gap in small businesses: Some new evidence. International Journal of Business, 1: 65-80. 